\title{
ASSESSMENT OF DENTAL ANXIETY IN CHILDREN AND MOTHERS DURING FIRST DENTAL VISIT
}

Dr.Priyanka Gupta ${ }^{3}$, Dr. Sadanand Kulkarni ${ }^{1}$, Dr. Arunkumar Sajjanar ${ }^{1}$, Dr. Niharika Gahlod ${ }^{2}$, Dr.Manveen Lamba $^{3}$, Dr. Sumit Rajewar ${ }^{3}$

1- Professor, 2- Senior Lecturer, 3- Postgraduate Student, Department of Pedodontics and Preventive Dentistry, Swargiya Dadasaheb Kalmegh Smruti Dental College and Hospital, Nagpur

\section{ABSTRACT}

Aim and objectives: To evaluate the behavior changes in children aged 4-6 years and correlate the physiological variations in children and their mothers during first dental visit, and assess the influence of maternal anxiety on child's anxiety. Materials and methods: 60 children of 4-6 years accompanied by their mother visiting the Department of Pedodontics and Preventive dentistry for the first time. Frankle's behavior rating scale was used to record behavior of children. The blood pressure and heart rate was measured with digital blood pressure and heart rate monitor with wrist cuff and oxygen saturation with pulse oximeter and same were used to evaluate the physiological variations in the mother. Result: Significant Changes in systolic blood pressure and heart rate in children $(\mathrm{p}=0.0001, \mathrm{p}=0.0001)$ were observed while waiting and on completion of the procedure Gradual lowering of blood pressure and heart rate after procedure $(\mathrm{p}=0.0001)$ Mothers were anxious while waiting and less anxious after procedure $(\mathrm{p}=0.0001, \mathrm{p}=0.0001)$ Conclusion: Majority of the children exhibited high anxiety initially while waiting .The anxiety gradually diminished after procedure which was observed through their positive behavior. Maternal anxiety was high while waiting which gradually comes down after procedure Maternal anxiety does have some impact on the child's anxiety at least initially.

KEYWORDS: Dental Anxiety, First dental visit, fear, mother's anxiety, pulse rate

\section{INTRODUCTION}

Anxiety is usually classified as a disorder of neurotic nature and is often related to context of stress, with symptoms that may include worries, motor tension and even autonomic hyperactivity. ${ }^{1}$ The word emotion is not only related to joy, anger, fear, or sympathy but encompasses a whole lot of feeling and their interaction. ${ }^{2}$ Prediction of any uncomfortable situation invokes a feeling of fear which can be grouped as anxiety.
Anxiety related to dental treatment is well known. Dental anxiety is multifactorial, and is far more complex than can be explained by a single contributing factor. There is quite variation in international literature for prevalence of childhood dental anxiety in different population and age group i.e $3 \%$ to $43 \%{ }^{3,4,5}$ Usually the common perception in relation to dental treatment is pain and discomfort, and their perception affects the behavior of pediatric dental patient. 
Dental anxiety presents a challenge to the child, parents and the dental team. This leads to difficulty in behavior management, avoidance of dental care, and poorer oral health outcomes. ${ }^{6}$ So to overcome these problems and provide appropriate diagnosis and treatment and to instil a positive attitude toward dental treatment in children it is necessary to assess dental anxiety. ${ }^{7}$ Mothers are usually blamed for the child's anxiety. However sequel reaction of parental dental anxiety on their children dental anxiety is a controversial issue among researchers. According to Goettems ML et al., Leal AM et al., Tong HJ et al. ${ }^{8,9,10}$ there is a direct relation whereas according to Ten Berge $\mathrm{M}$ et al, Cox IC et al cannot confirm the finding. ${ }^{11,12}$ Presence of anxious people around children may be the reason for the development of anxiety in them. ${ }^{13}$ Dental anxiety is a complex phenomenon that is influenced by personality characteristics, fear of pain, traumatic dental experiences in childhood and dentally anxious family members or peers. ${ }^{14,15}$ Parental and child dental fear has a significant relation. ${ }^{16}$ Children are also prone to anxiety as of adults and the possible reason behind their development of anxiety is from peer communication of reported bad experiences or even from threats that parents make. ${ }^{17}$ So the clinical and psychological management becomes more difficult due to different understanding level's of children. Lee et al. suggested that the anxious behavior of adults during dental treatment may have been acquired through childhood fears, which would therefore require dentists to properly handle child patients. ${ }^{18}$ Unavoidable result of anxiety is changes in the physiological parameters like heart rate, blood pressure and oxygen saturation. Afferent fibers carry stressful stimuli from sense organs to the CNS. From there adrenal medulla is directly stimulated through preganglionic sympathetic fibers which in turn releases several stress hormones like adrenaline and this increases the blood pressure. Sympathetic stimulation increases directly the heart rate. ${ }^{19}$ So recognizing and managing child's/ patient's anxiety and behavior is very important aspect for doing a successful dental treatment. Frankl's behavior rating scale, is commonly used scale in dentistry due to its ease of learning and usage. Allows quick classification of child patient in one of the four categories: definitely negative, positive, negative, and definitely positive. ${ }^{20,21}$ In multiple visit child's response have been studied in relation to dental treatment. $^{22,23,24}$ Child's response is found to be improved with subsequent visit by many researchers but according to Venham et al response pattern was very complicated in multiple visits. ${ }^{23,24}$ This study aims to assess the changes in anxiety pattern of children and their behavior during first dental visit i.e. while waiting, during procedure and after procedure. Another important aspect of this study is to assess the anxiety pattern in mothers during first dental visit. This might help to assess influence of maternal anxiety extend along the course of treatment of children.

\section{MATERIAL AND METHODS}

A cross-sectional descriptive study was conducted in Department of Pedodontics and preventive dentistry with a sample size of 60 between the age group of 4 to 6 years reporting to the department accompanying their mothers for the first time. Ethical clearance was obtained from the Institutional Ethical Committee. Parent's consent and child's assent were obtained. Heart rate, blood pressure and oxygen saturation was assessed for child and their mother while waiting, during procedure and after procedure. A simple procedure of oral prophylaxis was carried out in the study.

Physiological parameters were recorded using Digital Blood Pressure and Heart Rate Monitor with Wrist Cuff and Pulse Oximeter. Children were noted for their behavior while waiting, during procedure and after procedure. Behavior was noted with Frankl's behavior rating scale. Children and mothers with any systemic condition, children requiring emergency line of treatment and not willing to participate were excluded. 
Statistical analysis was done by using descriptive and inferential statistics using chi square test and student's paired t test and software used in the analysis were SPSS 22.0 version and GraphPad Prism 7.0 version and $\mathrm{p}<0.05$ is considered as level of significance.

\section{RESULTS}

Table No.1: Comparison of Systolic Blood Pressure at waiting, during procedure and after procedure for children

\begin{tabular}{|c|c|c|c|c|c|c|c|c|}
\hline & \multicolumn{5}{|c|}{ Paired Differences } & \multirow{3}{*}{ t-value } & \multirow{3}{*}{ df } & \multirow{3}{*}{ p-value } \\
\hline & & & & \multicolumn{2}{|c|}{$\begin{array}{c}95 \% \text { Confidence Interval of the } \\
\text { Difference }\end{array}$} & & & \\
\hline & Mean & $\begin{array}{c}\text { Std. } \\
\text { Deviation }\end{array}$ & $\begin{array}{l}\text { Std. Error } \\
\text { Mean }\end{array}$ & Lower & Upper & & & \\
\hline $\begin{array}{l}\text { Waiting - During } \\
\text { Procedure }\end{array}$ & 11.00 & 6.68 & 0.86 & 9.27 & 12.72 & 12.73 & 59 & $0.0001, \mathbf{S}$ \\
\hline $\begin{array}{l}\text { Waiting - After } \\
\text { Procedure }\end{array}$ & 16.25 & 7.95 & 1.02 & 14.19 & 18.30 & 15.82 & 59 & $0.0001, \mathbf{S}$ \\
\hline $\begin{array}{l}\text { During Procedure } \\
\text { - After Procedure }\end{array}$ & 5.25 & 7.88 & 1.01 & 3.21 & 7.28 & 5.15 & 59 & $0.0001, \mathbf{S}$ \\
\hline
\end{tabular}

Table No.2 : Comparison of Diastolic Blood Pressure at waiting, during procedure and after procedure for children

\begin{tabular}{|c|c|c|c|c|c|c|c|c|}
\hline & \multicolumn{5}{|c|}{ Paired Differences } & \multirow{3}{*}{ t-value } & \multirow{3}{*}{ df } & \multirow{3}{*}{$\mathrm{p}$-value } \\
\hline & & & & $\begin{array}{r}95 \% \text { Confid } \\
\text { D }\end{array}$ & rval of the & & & \\
\hline & Mean & $\begin{array}{c}\text { Std. } \\
\text { Deviation }\end{array}$ & Std. Error Mean & Lower & Upper & & & \\
\hline $\begin{array}{l}\text { Waiting - During } \\
\text { Procedure }\end{array}$ & 1.95 & 3.92 & 0.50 & 0.93 & 2.96 & 3.84 & 59 & $0.025, \mathbf{N S}$ \\
\hline $\begin{array}{c}\text { Waiting - After } \\
\text { Procedure }\end{array}$ & 5.20 & 6.92 & 0.89 & 3.41 & 6.98 & 5.81 & 59 & $0.021, \mathbf{N S}$ \\
\hline $\begin{array}{l}\text { During Procedure - } \\
\text { After Procedure }\end{array}$ & 3.25 & 6.28 & 0.81 & 1.62 & 4.87 & 4.00 & 59 & 0.011,NS \\
\hline
\end{tabular}


Table No.3: Comparison of Oxygen Saturation for children

\begin{tabular}{|c|c|c|c|c|c|c|c|c|}
\hline & \multicolumn{5}{|c|}{ Paired Differences } & \multirow{3}{*}{ t-value } & \multirow{3}{*}{$\mathrm{df}$} & \multirow{3}{*}{$\mathrm{p}$-value } \\
\hline & & & & \multicolumn{2}{|c|}{$\begin{array}{c}95 \% \text { Confidence } \\
\text { Interval of the } \\
\text { Difference }\end{array}$} & & & \\
\hline & Mean & $\begin{array}{c}\text { Std. } \\
\text { Deviation }\end{array}$ & $\begin{array}{c}\text { Std. Error } \\
\text { Mean }\end{array}$ & Lower & Upper & & & \\
\hline $\begin{array}{l}\text { Waiting - During } \\
\text { Procedure }\end{array}$ & 0.15 & 1.16 & 0.15 & -0.15 & 0.45 & 1.00 & 59 & $0.321, \mathbf{N S}$ \\
\hline $\begin{array}{l}\text { Waiting - After } \\
\text { Procedure }\end{array}$ & 0.55 & 1.40 & 0.18 & 0.18 & 0.91 & 3.02 & 59 & $0.014, \mathbf{N S}$ \\
\hline $\begin{array}{c}\text { During Procedure - } \\
\text { After Procedure }\end{array}$ & 0.40 & 1.12 & 0.14 & 0.10 & 0.69 & 2.75 & 59 & $0.028, \mathbf{N S}$ \\
\hline
\end{tabular}

Table No.4: Comparison of Heart Rate for children

\begin{tabular}{|c|c|c|c|c|c|c|c|c|}
\hline & \multicolumn{5}{|c|}{ Paired Differences } & \multirow{3}{*}{ t-value } & \multirow{3}{*}{$\mathrm{df}$} & \multirow{3}{*}{$\mathrm{p}$-value } \\
\hline & & & & \multicolumn{2}{|c|}{$\begin{array}{l}95 \% \text { Confidence Interval of } \\
\text { the Difference }\end{array}$} & & & \\
\hline & Mean & Std. Deviation & $\begin{array}{l}\text { Std. Error } \\
\text { Mean }\end{array}$ & Lower & Upper & & & \\
\hline $\begin{array}{l}\text { Waiting - During } \\
\text { Procedure }\end{array}$ & 9.85 & 7.50 & 0.96 & 7.91 & 11.78 & 10.17 & 59 & $0.0001, \mathbf{S}$ \\
\hline $\begin{array}{l}\text { Waiting - After } \\
\text { Procedure }\end{array}$ & 24.60 & 8.72 & 1.12 & 22.34 & 26.85 & 21.84 & 59 & $0.0001, \mathbf{S}$ \\
\hline $\begin{array}{l}\text { During Procedure - } \\
\text { After Procedure }\end{array}$ & 14.75 & 8.87 & 1.14 & 12.45 & 17.04 & 12.87 & 59 & $0.0001, \mathbf{S}$ \\
\hline
\end{tabular}


Table No.5 : Comparison of Systolic Blood Pressure for mothers

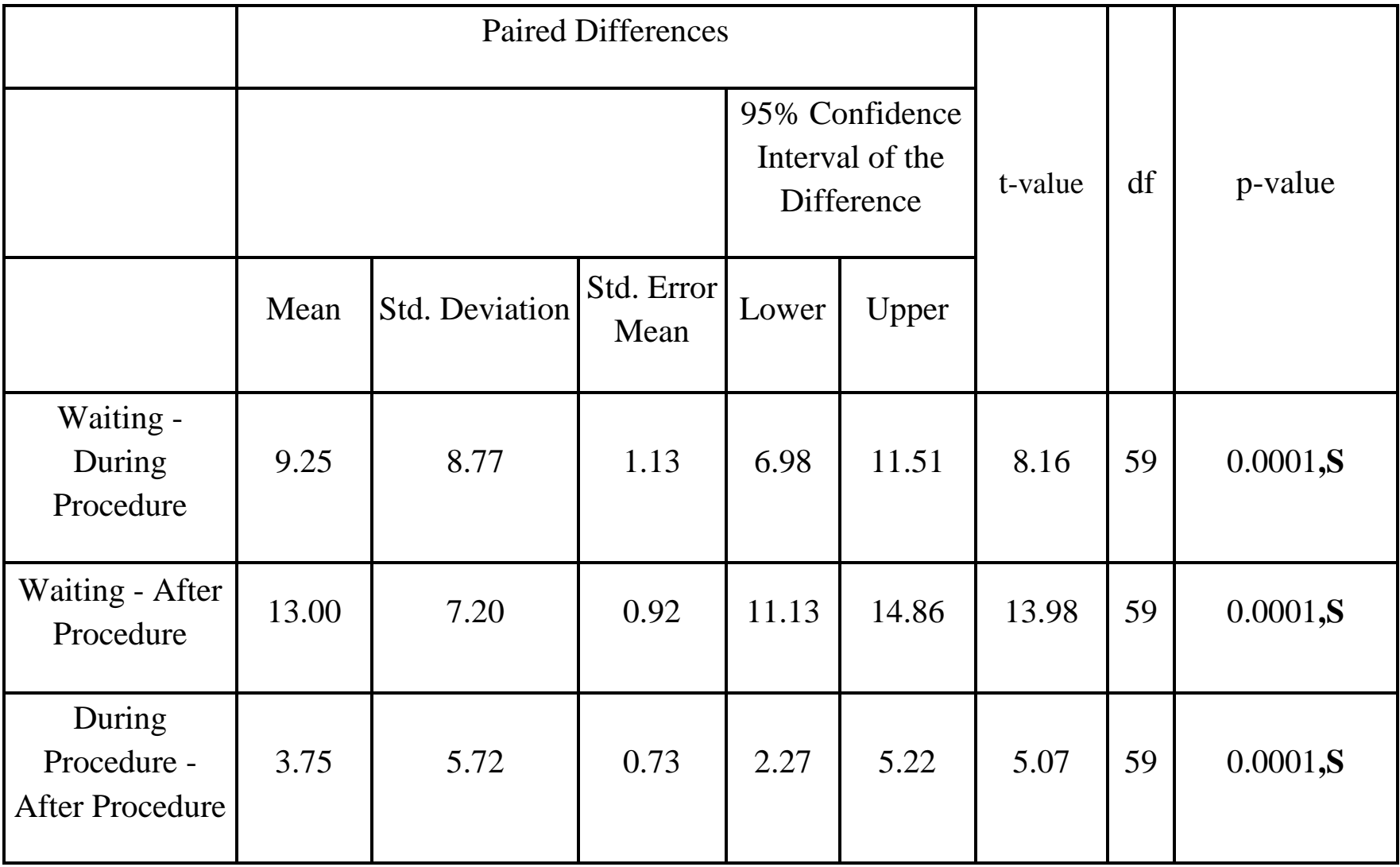

Table No.6: Comparison of Diastolic Blood Pressure for mothers

\begin{tabular}{|c|c|c|c|c|c|c|c|c|}
\hline & Paired D & ferences & & & & & & \\
\hline & & & & $\begin{array}{l}95 \% \text { Confi } \\
\text { Interval of } \\
\text { Difference }\end{array}$ & & t-value & $\mathrm{df}$ & $\mathrm{p}$-value \\
\hline & Mean & $\begin{array}{c}\text { Std. } \\
\text { Deviation }\end{array}$ & $\begin{array}{c}\text { Std. Error } \\
\text { Mean }\end{array}$ & Lower & Upper & & & \\
\hline $\begin{array}{l}\text { Waiting - During } \\
\text { Procedure }\end{array}$ & 3.85 & 4.82 & 0.62 & 2.60 & 5.09 & 6.17 & 59 & $0.031, \mathbf{N S}$ \\
\hline $\begin{array}{l}\text { Waiting - After } \\
\text { Procedure }\end{array}$ & 5.25 & 6.06 & 0.78 & 3.68 & 6.81 & 6.70 & 59 & $0.021, \mathbf{N S}$ \\
\hline \begin{tabular}{|l|} 
During \\
Procedure - \\
After Procedure
\end{tabular} & 1.40 & 4.28 & 0.55 & 0.29 & 2.50 & 2.53 & 59 & $0.014, \mathbf{N S}$ \\
\hline
\end{tabular}


Table no:7 Comparison of Oxygen Saturation for mothers

\begin{tabular}{|c|c|c|c|c|c|c|c|c|}
\hline & \multicolumn{5}{|c|}{ Paired Differences } & \multirow{3}{*}{$\mathrm{t}$-value } & \multirow{3}{*}{$\mathrm{df}$} & \multirow{3}{*}{ p-value } \\
\hline & & & & \multicolumn{2}{|c|}{$\begin{array}{l}\text { 95\% Confidence } \\
\text { Interval of the } \\
\text { Difference }\end{array}$} & & & \\
\hline & Mean & Std. Deviation & $\begin{array}{c}\text { Std. Error } \\
\text { Mean }\end{array}$ & Lower & Upper & & & \\
\hline $\begin{array}{l}\text { Waiting - During } \\
\text { Procedure }\end{array}$ & 0.30 & 0.78 & 0.10 & 0.09 & 0.50 & 2.95 & 59 & $0.025, \mathrm{NS}$ \\
\hline $\begin{array}{l}\text { Waiting - After } \\
\text { Procedure }\end{array}$ & 0.95 & 2.22 & 0.28 & 0.37 & 1.52 & 3.31 & 59 & $0.032, \mathrm{NS}$ \\
\hline $\begin{array}{l}\text { During Procedure - } \\
\text { After Procedure }\end{array}$ & 0.65 & 2.32 & 0.30 & 0.04 & 1.25 & 2.16 & 59 & $0.0345, \mathrm{NS}$ \\
\hline
\end{tabular}

Table no: 8 Comparison of Heart Rate for mothers

\begin{tabular}{|c|c|c|c|c|c|c|c|c|}
\hline & \multicolumn{5}{|c|}{ Paired Differences } & \multirow{3}{*}{ t-value } & \multirow{3}{*}{ df } & \multirow{3}{*}{ p-value } \\
\hline & & & & \multicolumn{2}{|c|}{$\begin{array}{l}95 \% \text { Confidence } \\
\text { Interval of the } \\
\text { Difference }\end{array}$} & & & \\
\hline & Mean & $\begin{array}{c}\text { Std. } \\
\text { Deviation }\end{array}$ & $\begin{array}{l}\text { Std. Error } \\
\text { Mean }\end{array}$ & Lower & Upper & & & \\
\hline $\begin{array}{c}\text { Waiting - During } \\
\text { Procedure }\end{array}$ & 9.95 & 5.32 & 0.68 & 8.57 & 11.32 & 14.48 & 59 & $0.0001, \mathrm{~S}$ \\
\hline Waiting - After Procedure & 20.20 & 6.29 & 0.81 & 18.57 & 21.82 & 24.85 & 59 & $0.0001, \mathrm{~S}$ \\
\hline $\begin{array}{c}\text { During Procedure - After } \\
\text { Procedure }\end{array}$ & 10.25 & 6.71 & 0.86 & 8.51 & 11.980 & 11.81 & 59 & $0.0001, \mathrm{~S}$ \\
\hline
\end{tabular}




\section{Graph 1: Comparison of SBP among child and mother}

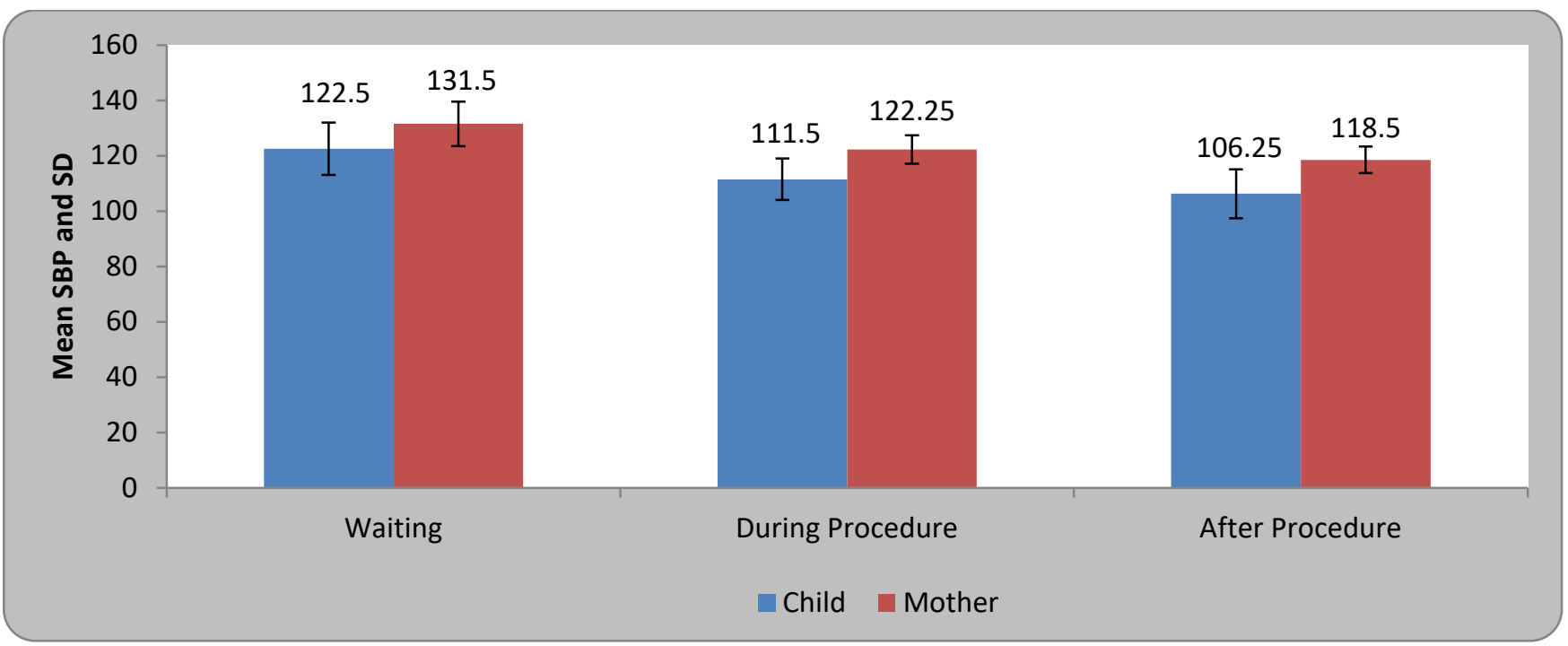

\section{Graph 2: Comparison of DBP among child and mother}

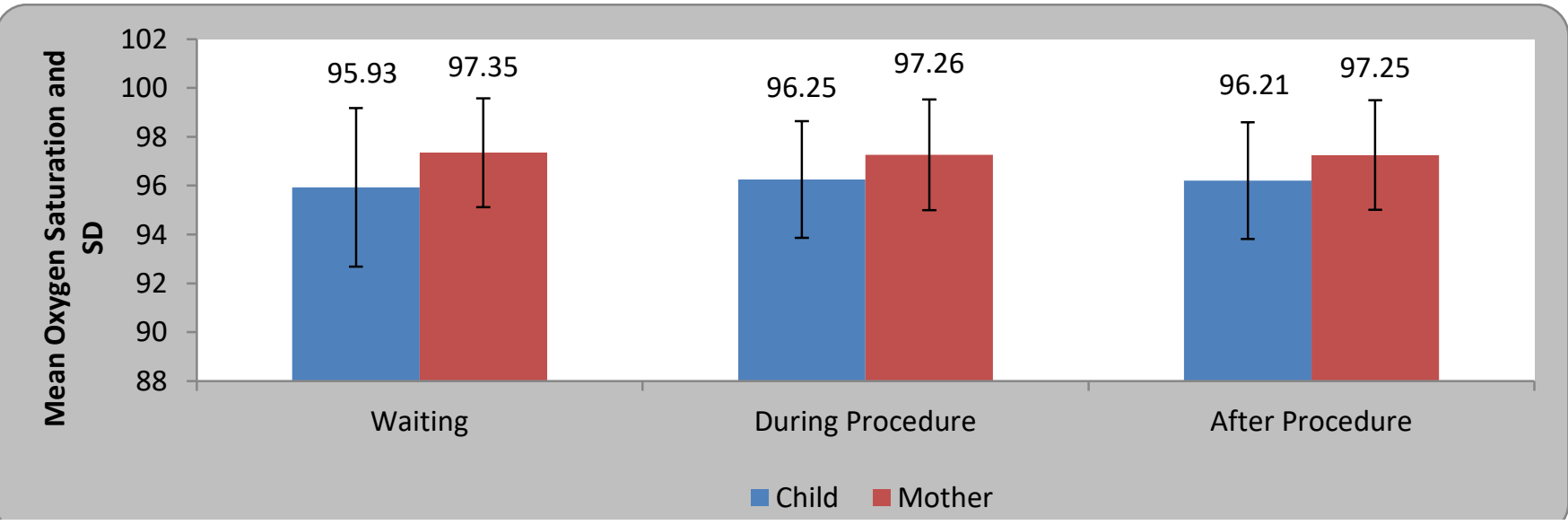

Graph 3: Comparison of oxygen saturation among child and mother

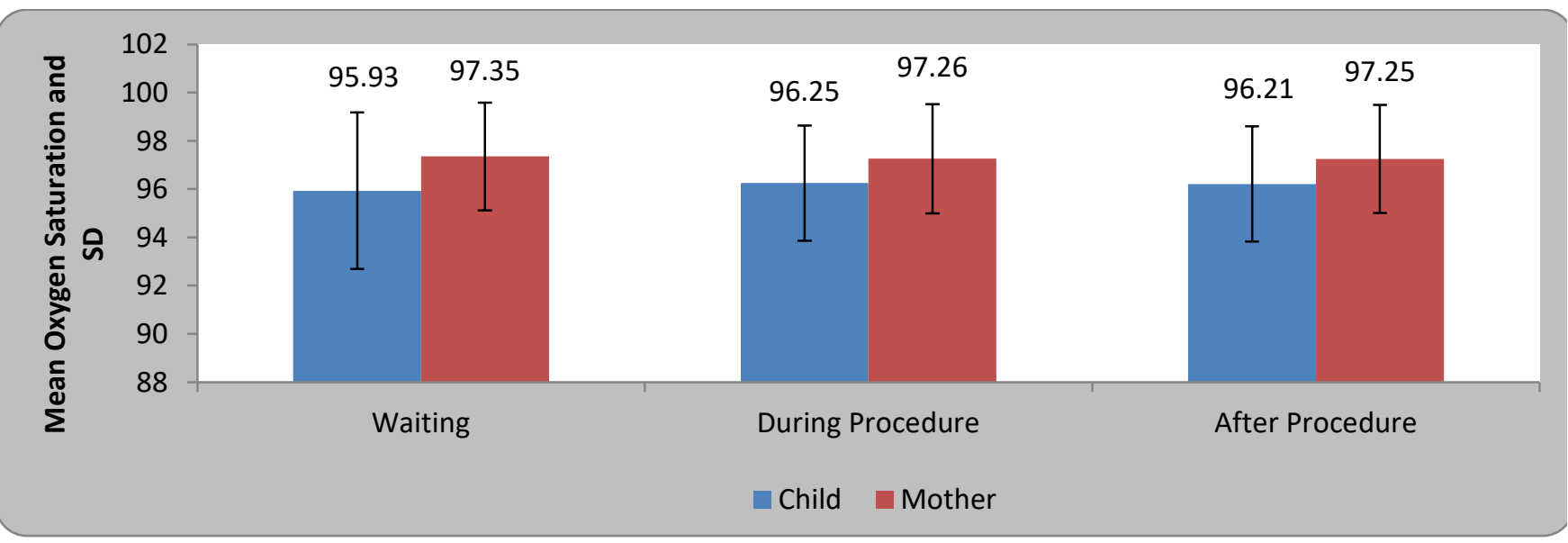




\section{Graph 4: Comparison of heart rate among child and mother}

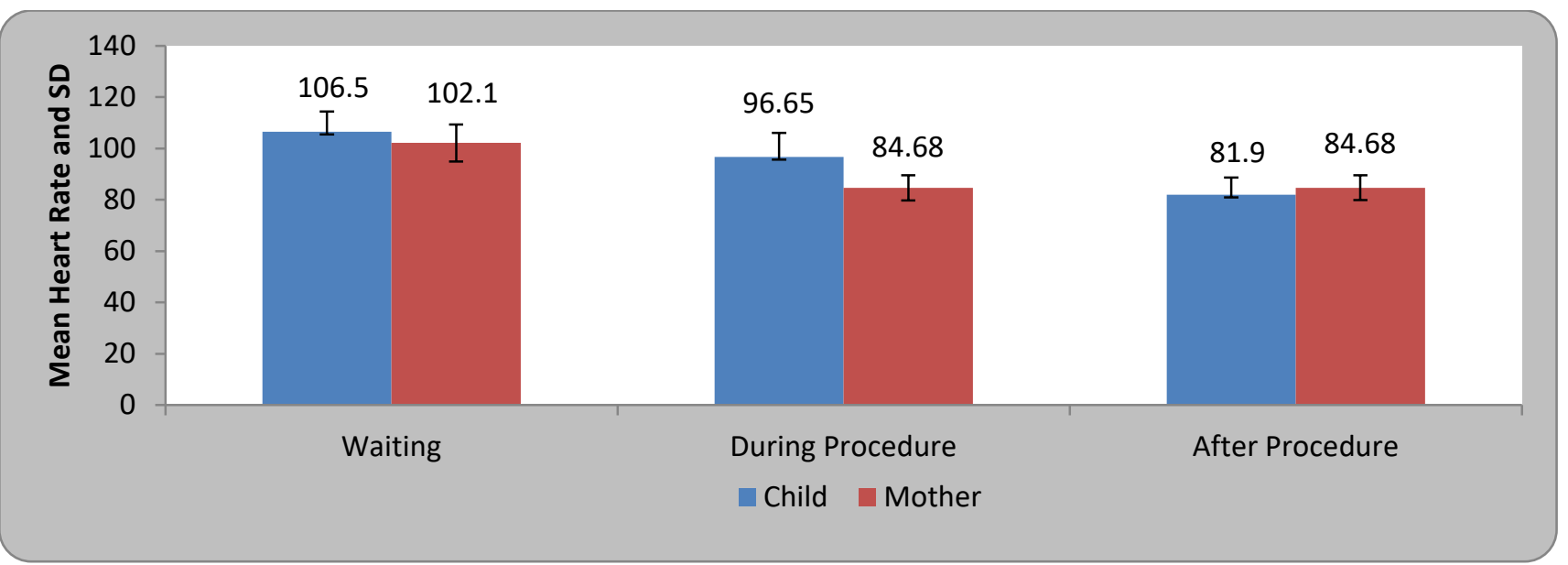

\section{DISCUSSION}

Anxiety is a fear of unknown, which is a form of emotion, and is associated with changes in blood pressure and heart rate. Anxiety can be seen from two different aspect i.e psychological and physiological aspect. ${ }^{25}$ It is been proved that stress produces anxiety, which activates a chain of physiological reactions which ultimately affects the heart rate and blood pressure. ${ }^{26}$ Any of the senses like sight, smell, sound, touch or taste may produces the physiological variation. Afferent fibers carry the sensations from sensory organs to CNS. Adrenal medulla is stimulated by preganglionic sympathetic fibers there by secreting stress hormones. This profoundly causes increase in blood pressure. ${ }^{27}$

Emotional outburst associated with fear can produces changes in heart rate, blood pressure, even can cause frank fainting and death. ${ }^{28}$

Johnson and Baldwin was one of the first to identify a positive and significant correlation between maternal anxiety and the repertoire of behavior of children who were undergoing treatment. ${ }^{29}$ Anxiety among children and their mothers during dental treatment is one of the challenges faced by the dentist. Hence it is important to assess the patient's anxious behavior, so that technique for achieving clinical security may be applied. ${ }^{30}$
The results of this study clearly showed a statistically significant change in the systolic blood pressure and heart rate of children and mothers while waiting, during procedure and after procedure.[Table no. 1,3,5,8] According to Best and Taylor $^{31}$ emotional excitement tends to increase arterial blood pressure, particularly the systolic phase and heart rate also increased. Increase in systolic blood pressure and heart rate initially i.e while waiting may be due to the fear of unknown. Venham and Quatrolli ${ }^{24}$ stated that fear of unknown is responsible for the initial reaction of a child to dental visit. And also Venham et $\mathrm{al}^{23}$ concluded that during initial visit, child showed a higher negative behavior, and the initial dental experience sensitizes the child to the dental treatment.

It was observed in our study that there was gradual lowering of blood pressure and heart rate of children after procedure. Might be after initial commencing i.e after oral examination and a simple procedure of oral prophylaxis the children probably got sensitized to the environment and dental setting which might have resulted in their near to normal physiological paramaters and positive behavior after procedure. There was no significance found with diastolic blood pressure and oxygen saturation of children and mothers. [Table no: 2,3,6,7] 
Comparison of Frankle's behavior rating scale score showed that children showed definitely negative behavior while waiting and gradually their behavior was positive after procedure. Initial definitely negative behavior may be due to new environment and a fear of procedure to be carried out on them.

Ripa (1979) concluded that in almost all children and specially in pre-school children some degree of apprehension or anxiety is experienced during their dental visit. $^{32}$ Taylor et al stated that negative behavior of pre-school children in initial phase of treatment was due to separation anxiety and fear of unknown. ${ }^{33}$

The physiological changes in mother and children showed the similar pattern. Maternal anxiety imparts some form of fear to their children which are manifested as changes in systolic blood pressure and heart rate. Mother's higher physiological parameters, gradually came to the normal or near normal during procedure and after procedure. The initial anxiety may be due to the anticipation of the dental procedure and fear of unknown. And on seeing their children's improving attitude towards the treatment, might have gradually reduced their anxiety.

However the results of the study cannot be generalized due to small sample size, study with larger sample size should be carried out.

\section{CONCLUSION}

Supported with the knowledge of child's anxiety application of appropriate behavior management technique becomes easier. This facilitates to provide best treatment to the child patient and helps to instill a positive attitude towards the dental treatment.

Financial support and sponsorship: Nil.

Conflicts of interest: There are no conflicts of interest.

\section{REFERENCES}

1. World Health Organization. The ICD-10 Classification of Mental and Behavioural Disorders. Diagnostic criteria for research. Geneva, 1993.

2. Patir MA, Beyza AB, Erol T. Assessment of the feelings and attitudes of children towards their dentists and their association with oral health. ISRN Dent 2014; 2014:1-4.

3. Klingberge G, Berggren U, Noren JG. Dental fear in an urban Swedish population: prevalence and concomitant factors. Community Dent Health;11:208-14.1994.

4.Wogelius.P, Poulsen S, Sorensen HT. Prevalence of dental anxiety and behavior management problems among six to eight year old Danish $\mathrm{H}$, Milgrom P, Honkanen A, Karjalainen M, Tay KM.

5. Lee CY, Chang YY, Huang ST. Prevalence of dental anxiety among 5-8 years old Taiwanese children. J Public Health Dent;67: 36-41,2007.

6. Merdad L, El-Housseiny AA. Do children's previous dental experience and fear affect their perceived oral health-related quality of life (OHRQoL)? BMC Oral Health. 2017;17:47.

7. Buchanan H, Niven N. Validation of a facial image scale to assess child dental anxiety. Int $\mathrm{J}$ Paediatr Dent. 2002;12:47-52.

8. Goettems ML, Ardenghi TM, Romano AR, Demarco FF, Torriani DD. Influence of meternal dental anxiety on the child's dental caries experience Caries Res;46(1):3-8.2012.

9. Leal AM, SerraKG, Queiroz RC, Araujo MA, Maia Filho EM. F the dentaear and /or anxiety of children and parents associated with the dental environment. Eur J Paediatr Dent.Dec;14(4): $267-$ 72.2013 .

10. Tong HJ, Khong J, Ong C, Ng A, Lin Y, Ng JJ , Hong CH, Children's and parent's attitude towards dentist' appearance, child dental experience and their relationship with dental anxiety. Eur Arch Paediatr Dent. May 20.215,2014. 
11. Ten Berge M,Veerkamp JS , Hoogstraten J, PrinsPJ. Childhood dental fear in relation to parental child rearing attitude. Psychol Res.;92(1):43-50.2003.

12. Cox IC, Krikken JB, Veerkamp JS. Influence of parental presences on the child perceptions of, and behavior, during dental treatment. Eur Arch Paediatr Dent.Aug;12(4):200-4.2011.

13.Cohen SM, Fiske J, Newton JT. The impact of dental anxiety on daily living. $\mathrm{Br}$ Dent $\mathrm{J}$. 2000;189:385-90.

14.Hmud R, Walsh L. Dental anxiety: causes, complications and management approaches. Journal of Minimum Intervention in Dentistry. 2009;2:6778.

15. Porritt J, Marshman Z, Rodd HD. Understanding children's dental anxiety and psychological approaches to its reduction. International journal of paediatric dentistry / the British Paedodontic Society and the International Association of Dentistry for Children. 2012;22:397405.

16. Themessl-Huber M, Freeman R, Humphris G, MacGillivray S, Terzi N. Empirical evidence of the relationship between parental and child dental fear: a structured review and meta-analysis. International journal of paediatric dentistry / the British Paedodontic Society and the International Association of Dentistry for Children. 2010; 20:83101.

17. Carvalho RWF, Cardoso MSO, Falcão PGCB, et al. Anxiety regarding dental treatment: prevalence and predictors among Brazilians. CiênSaúdeColetiva. 2012;17(7):1915-22.

18. Lee CY, Chang YY, Huang ST. The clinically related predictors of dental fear in Taiwanese children. Int J Paediatr Dent. 2008;18(6):415-22.

19. Guyton AC. Textbook of Medical Psychology. 8th ed. Bangalore, India: Prism Books; 1991.

20.Frankl SN,Shire FR, Fogels HR. Should the parent remain with the child in the dental operatory? J Dent Child 1962 Apr; 29(2):150-162.
21. Dentistry AA. Guideline on behavior guidance for the pediatric dental patient.Pediatr Dent 2011;43:28-32.

22. Mittal R, Sharma M. Assessment of psychological effects of dental treatment on children. Contemp Clin Dent 2012;3 Suppl 1:S2-7.

23. Venham L, Bengston D, Cipes M. Children's response to sequential dental visits. J Dent Res 1977;56:454-9.

24. Venham L, Quatrocelli S. The young child's response to repeated dental procedures. J Dent Res 1977;56:734-8.

25. Darrow CW: Physiological and clinical tests of autonomic function and autonomic balance, Physiol Rev, 23: 1, 1943.

26. Best CH, Taylor NB: The physiological basis of medical practice. The Williams and, Williams and Wilkins Co, Baltimore, pages: 4:99-115, 1980. 127 205, 1945.

27. Messer JG: Stress in dental patients Children's undergoing routine procedures, J Dent Res, 56(4): 362367,1977

28. Bagchi A, Lahiri B, Jalaluddin M, Kumar G, Das S, Dhull KS. Quantification and measurement of changes in anxiety level in preschool children and their mothers through multiple-visit dental treatment. J Int Soc Prevent Communit Dent 2017;7:125-30.

29 .Johnson R, Baldwin DC Jr. Maternal anxiety and child behavior. ASDC J Dent Child. 1969;36(2):87-92.

30. Lee CY, Chang YY, Huang ST. The clinically related predictors of dental fear in Taiwanese children. Int J Paediatr Dent. 2008;18(6):415-22.

31. Best CH, Taylor NB. The Psychological Basis of Medical Practice. Baltimore: The Williams and Williams and Wilkins Co.; 1945. p. 127, 205.

32. Ripa LW. Maternal influence on children's behaviour in the dental situation. In: Ripa LW, Barenie JA, editors. Management of Dental 
Behaviour in Children.Littletion, Massachusetts: P.S.G. Publishing Company; 1979. p. 15-26.

33. Mark Taylor H, Ira Moyer $\mathrm{N}$ and Devereaux Peterson S: Effect of appointment time, age and gender on children's behavior in a dental setting, $\mathrm{J}$ Dent Child, 106-110, 1983. 